\title{
IMPLEMENTASI SIG UNTUK PEMETAAN USAHA MIKRO, KECIL DAN MENENGAH (UMKM) PRODUK KHAS KOTA PALEMBANG
}

\author{
Eka Puji Agustini \\ Dosen Universitas Bina Darma \\ Jalan Jenderal Ahmad Yani No.3 Palembang \\ Sur-el : eka_puji@binadarma.ac.id
}

\begin{abstract}
Geographically the area of Palembang City is $400.61 \mathrm{~km} 2$ which is divided into 16 subdistricts and 107 villages and has a sizeable population. The Office of Cooperatives, Small and Medium Enterprises in Trade and Industry of Palembang City as an office directly related UMKM has mapped UMKM in Palembang City but this mapping is still limited to reporting, and is not yet widely accessible to the public. Therefore this study aims to map UMKM geographically and publicly accessible. This mapping will be built using Arcgis technology and Geographic Information System which is an application of earth data processing by looking at spatial data and attribute data. The results of this study are in the form of a GIS application that maps the UMKM of Palembang City.
\end{abstract}

Keywords: UMKM., GIS, Mapping, Data Spasial, Data Atribut

Abstrak: Secara geografis luas wilayah Kota Palembang 400,61 $\mathrm{km}^{2}$ yang terbagi dalam 16 kecamatan dan 107 kelurahan dan memiliki jumlah penduduk yang cukup besar hal ini seiring dengan pertumbuhan UMKM yang besar pula, setidaknya tercatat 37 ribu UMKM yang tersebar di wilayah Kota Palembang. UMKM di Kota Palembang telah dipetakan Oleh Dinas Terkait namun pemetaan ini belum menggunakan Sistem Informasi Geografis (SIG), oleh karena itu penelitian ini bertujuan untuk memetakan UMKM secara geografis untuk memudahkan dalam pengolahan data secara geografis dan mempercepat penyampaian informasi terkait pembinaan UMKM. Pemetaan ini akan dibanggun dengan menggunakan teknologi Arcgis dan Sistem Informasi Geografis yang merupakan aplikasi penggolahan data kebumian dengan melihat data spasial dan data atribut. Hasil penelitian ini berupa aplikasi GIS yang memetakan UMKM Kota Palembang.

Kata kunci: UMKM, SIG, Pemetaan, Data Spasial, Data Atribut

\section{PENDAHULUAN}

Usaha Mikro, Kecil, dan Menengah (UMKM) diatur dalam Undang Undang Republik Indonesia No. 20 Tahun 2008 tentang UMKM, yang menjelaskan bahwa yang dinyatakan Usaha Mikro adalah usaha produktif milik orang perorangan dan/atau badan usaha perorangan yang memenuhi kriteria usaha mikro. Dan Usaha Kecil adalah usaha ekonomi produktif yang berdiri sendiri, yang dilakukan oleh orang perorangan atau badan usaha yang bukan merupakan anak perusahaan atau bukan cabang perusahaan yang dimiliki, dikuasai, atau menjadi bagian baik langsung maupun tidak langsung dari Usaha Menengah atau Usaha Besar yang memenuhi kriteria Usaha Kecil. Sedangkan Usaha Menengah adalah usaha ekonomi produktif yang berdiri sendiri, yang dilakukan oleh orang perorangan atau badan usaha yang bukan merupakan anak perusahaan atau cabang perusahaan yang dimiliki, dikuasai, atau menjadi bagian baik langsung maupun tidak langsung dengan Usaha Kecil atau Usaha Besar 
dengan jumlah kekayaan bersih atau hasil penjualan tahunan sebagaimana diatur dalam Undang Undang ini. [1]

(UMKM) merupakan salah satu kegiatan usaha yang mampu memperbanyak lapangan kerja dan dapat memberikan pelayanan ekonomi secara luas kepada masyarakat, selain itu juga sangat berperan dalam proses pemerataan dan peningkatan pendapatan masyarakat, sehingga mendorong pertumbuhan ekonomi di suatu daerah, dan mewujudkan stabilitas ekonomi nasional. Namun, pada era globalisasi saat ini dan mendatang, peran keberadaan UMKM semakin penting yakni sebagai salah satu sumber devisa ekspor non-migas Indonesia. [2] Hal ini sesuai dengan tujuan yang tertera dalam Undang Undang Republik Indonesia No. 20 Tahun 2008, bahwa Usaha Mikro, Kecil, dan Menengah bertujuan menumbuhkan dan mengembangkan usahanya dalam rangka membangun perekonomian nasional berdasarkan demokrasi ekonomi yang berkeadilan.

Secara geografis Kota Palembang terletak antara $2^{\circ} 52^{\prime}$ sampai $3^{\circ} 5^{\prime}$ Lintang Selatan dan $104^{\circ} 37^{\prime}$ sampai $104^{\circ} 52^{\prime}$ Bujur Timur dengan ketinggian rata-rata 8 meter dari permukaan air laut. Luas wilayah Kota Palembang sebesar $400,61 \mathrm{~km}^{2}$ yang secara administrasi terbagi atas 16 kecamatan dan 107 kelurahan. [3]

Dengan letak geografis yang cukup luas dan memiliki jumlah penduduk yang tinggi berdampak pula dengan pertumbuhan UMKM di kota Palembang, dimana hingga memasuki pertengahan tahun 2019 setidaknya tercatat 37 Ribu UMKM terdapat di Kota Palembang yang tersebar di 400,61 $\mathrm{K}^{2}$ wilayah tersebut, mulai dari skala rumahan hingga skala yang lebih besar. UMKM yang ada di Kota Palembang sangat bervariasi, baik berupa usaha kuliner, kerajinan tangan, pakaian dan lain sebagainya. [4].

Dinas Koperasi, Usaha Kecil Dan Menengah, Perdagangan Dan Perindustrian Kota Palembang sebagai salah satu dinas yang berkaitan langsung dengan UMKM di Kota Palembang, sudah memetakan UMKM di Kota Palembang, namun pemetaan belum dilakukan dengan sistem informasi geografis dan pemetaan ini masih di peruntukan untuk dinas tersebut. Oleh karena itulah penelitian ini akan membuat pemetaan UMKM yang nantinya memudahkan dalam penggolahan data secara geografis dan memudahkan dalam pelaporan maupun penyampaian informasi dan pengkoordinasian terkait pembinaan UMKM.

Adapun penelitian yang terkait dengan pemanfaatan sistem informasi geografis adalah pemanfaatan sistem informasi geografis (SIG) dalam aplikasi pelaporan dan pelacakan kejahatan berbasis android penelitian ini bertujuan membuat aplikasi pelaporan kejahatan yang bisa dipakai masyarakat secara menyeluruh di berbagai daerah. [5]. Selanjutnya penelitian yang berjudul pemanfaatan system informasi (SIG) untuk prioritas penanganan jalan di kabupaten Aceh Besar, penelitian ini menyatakan bahwa dengan Sistem Informasi Geografis (SIG) dapat mempermudah dan mempercepat dalam memberikan informasi terkait dengan penangannan jalan di Aceh Besar.[6] dan penelitian yang berjudul sistem informasi geografis (SIG) menentukan lokasi 
pertambangan batu bara di Provinsi Bengkulu berbasis website penelitian ini menghasilkan sebuah Aplikasi WebGIS pusat pertambangan di Provinsi Bengkulu, yang bertujuan agar pengguna lebih mudah dalam mendapatkan informasi mengenai lokasi pertambangan di Provinsi Bengkulu. [7]

\section{METODOLOGI PENELITIAN}

Penelitian ini menggunakan teknologi yaitu Arcgis dan Sistem Informasi Geograafis, yang merupakan aplikasi pengolahan data kebumian atau geografis dengan melihat data spatial dan data atribut yang dikenal juga data non spasial dengan menggunakan sistem komputerisasi [8]. Dalam penelitian ini SIG digunakan untuk membagi wilayah dimana terdapat UMKM dan memberikan informasi terkait dengan UMKM yang ada diwilayah tersebut.

\subsection{Perencanaan}

Pada tahap perencanaan pengembang mendefinisikan seluruh perangkat lunak, serta mengidentifikasikan semua kebutuhan sistem informasi geografis, dan garis besar sistem yang akan dibuat berfokus pada data produk khas Palembang seperti : data pempek, data kerupuk kemplang dan data songket yang ada di setiap kecamatan kota Palembang serta tinjauan umum apa saja yang digunakan sebagai panduan perencanaan penentuan kelengkapan apa saja yang diperlukan alat dan bahan yang dibutuhkan.

\subsection{Pengumpulan Data Penelitian}

Pada tahapan ini pegembang dan user mendefinisikan semua kebutuhan dari sistem infromasi geografis dengan mengikuti alur dari tahapan GIS dimana komponennya terdiri dari data spasial berupa data yang mengacu pada posisi, objek dan hubungan diantaranya dalam ruang bumi. [9]. Dan data non spasial data yang tidak memiliki orientasi keruangan (geografis) ataupun sistem koordinat dalam penggambarannya, atau hanya bersifat sebagai atribut saja (keterangan pelengkap) [10]. Pengembang sudah mendapatkan data spasial dan data non spasial yang dijabarkan dalam data penelitian seperti pada tabel 1 .

Tabel 1. Data Spasial dan Non Spasial UMKM Pempek

\begin{tabular}{|c|c|c|c|c|c|}
\hline No & Nama & Alamat & Titik Koordinat & Telepon & Buka \\
\hline 1 & Pempek Cek Nani & $\begin{array}{l}\text { kecamatan alang-alang } \\
\text { lebar }\end{array}$ & $\begin{array}{l}104.69184 \quad- \\
2.913278\end{array}$ & 711384011 & $06.00-22.00$ \\
\hline 2 & Pempek Candy & kecamatan Ilir Barat I & $\begin{array}{l}104744155- \\
2.986 .429\end{array}$ & 0711318246 & $06.00-21.00$ \\
\hline 3 & Nony 168 & kecamatan Ilir Barat I & $\begin{array}{l}104747107- \\
2.965956\end{array}$ & 0711322511 & $06.00-21.00$ \\
\hline 4 & Fapiku 238 & $\begin{array}{l}\text { kecamatan Alang- } \\
\text { alang lebar }\end{array}$ & $\begin{array}{l}104.7096198- \\
2.9440607 .\end{array}$ & 0711541144 & $10.00-22.00$ \\
\hline 5 & Pempek Vico & kecamatan Plaju & $\begin{array}{l}104.753897- \\
2.984047\end{array}$ & 0711581188 & $06.00-21.00$ \\
\hline 6 & Pak Raden & Kec. Bukit Kecil & $\begin{array}{l}104.746913- \\
2.980633 .\end{array}$ & 0711430911 & $06.00-21.00$ \\
\hline 7 & Pempek Dempo & kecamatan Ilir Barat I & $104.764046-$ & 0711511691 & $08.00-18.00$ \\
\hline
\end{tabular}




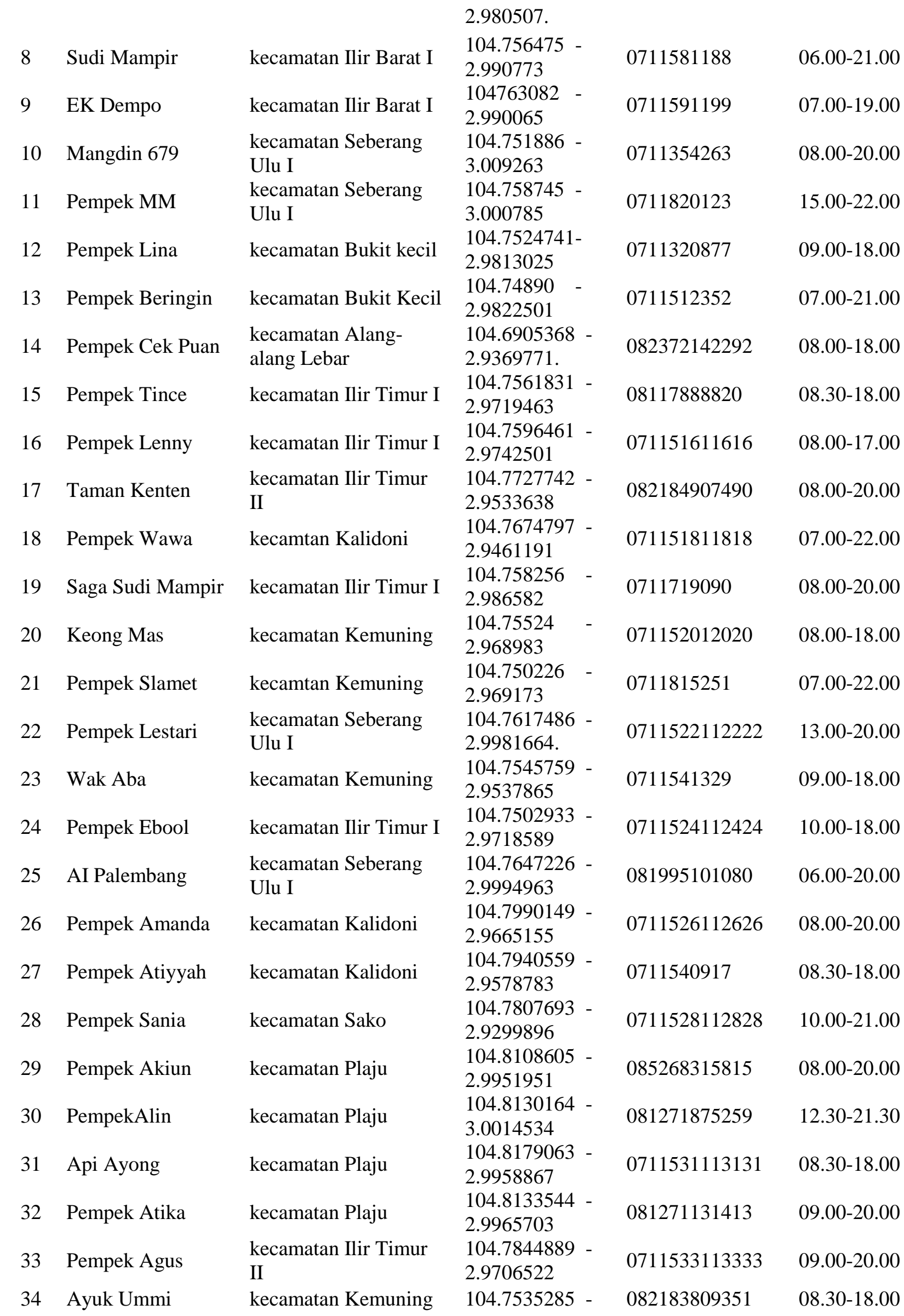




\begin{tabular}{|c|c|c|c|c|c|}
\hline & & & 2.9495692 & & \\
\hline 35 & Ayuk Ummi2 & kecamatan Kemuning & $\begin{array}{l}104.7545759 \\
2.9537865\end{array}$ & 082183809351 & $08.30-18.00$ \\
\hline 36 & Pempek Abai & Seberang Ulu I & $\begin{array}{l}104.7582559 \\
3.0011906\end{array}$ & 0711536113636 & $10.00-21.00$ \\
\hline 37 & Pempek Abel & $\begin{array}{l}\text { kecamatan Alang- } \\
\text { alang Lebar }\end{array}$ & $\begin{array}{l}104.7102191 \\
2.9223432\end{array}$ & 081377588006 & $11.00-22.00$ \\
\hline 38 & Pempek Acen & kecamatan Sukarami & $\begin{array}{l}104.7177295 \\
2.9157641\end{array}$ & 0711538113838 & $09.00-22.00$ \\
\hline 39 & Pempek Ating & kecamatan Bukit Kecil & $\begin{array}{l}104.7559747 \\
2.9863196\end{array}$ & 0711373178 & $08.30-18.00$ \\
\hline 40 & Pempek Atun & kecamatan Bukit Kecil & $\begin{array}{l}104.754703- \\
2.9906961\end{array}$ & 0711540114040 & $08.30-18.00$ \\
\hline 41 & Pempek Oza & kecamatan Bukit Kecil & $\begin{array}{l}104.7483621 \\
2.9875442\end{array}$ & 089664720581 & $09.00-20.00$ \\
\hline 42 & Pempek Yayang & kecamatan Bukit Kecil & $\begin{array}{l}104.7583874 \\
2.9876112\end{array}$ & 0711542114242 & $08.30-18.00$ \\
\hline 43 & Pempek Kevin & kecamatan Sukarami & $\begin{array}{l}104.6941074 \\
2.906284\end{array}$ & 081368466910 & $08.30-18.00$ \\
\hline 44 & Pempek Yummy & kecamatan Ilir Barat I & $\begin{array}{l}104.7241599 \\
2.9822999\end{array}$ & 0711544114444 & $08.30-18.00$ \\
\hline 45 & Pempek 809 Yuni & kecamatan Kalidoni & $\begin{array}{l}104.7979936 \\
2.9654475\end{array}$ & 0711350375 & $08.30-18.00$ \\
\hline 46 & Pempek Radial & kecamatan Bukit Kecil & $\begin{array}{l}104.747408- \\
2.9809541\end{array}$ & 0711546114646 & $08.30-18.00$ \\
\hline 47 & Hang Bidin & kecamatan Ilir Barat II & $\begin{array}{l}104.754325- \\
2.9940496\end{array}$ & 085267041372 & $08.30-18.00$ \\
\hline 48 & Pempek Udin & kecamatan Ilir Barat II & $\begin{array}{l}104.7544067- \\
2.994024\end{array}$ & 081316832902 & $08.30-18.00$ \\
\hline 49 & Udang Mak Ning & $\begin{array}{l}\text { kecamatan Seberang } \\
\text { Ulu II }\end{array}$ & $\begin{array}{l}104.7681413- \\
2.9915496 .\end{array}$ & 0711710809 & $08.30-18.00$ \\
\hline 50 & Pempek Thomas & $\begin{array}{l}\text { kecamatan Seberang } \\
\text { Ulu I }\end{array}$ & $\begin{array}{l}104.7581685- \\
3.0015752\end{array}$ & 071150115050 & $08.30-18.00$ \\
\hline
\end{tabular}

Tabel 2. Data Spasial dan Non Spasial UMKM Kemplang dan Kerupuk

\begin{tabular}{|c|c|c|c|c|c|}
\hline No & Nama & Alamat & Titik Koordinat & Telepon & Buka \\
\hline 1 & Suwandi & kecamatan Ilir Timur I & $\begin{array}{l}104.761584 \\
2.981649\end{array}$ & 711515012 & $06.00-22.00$ \\
\hline 2 & Cek Tura & $\begin{array}{l}\text { kecamatan Seberang } \\
\text { Ulu I }\end{array}$ & $\begin{array}{l}104.751404 \\
3.010292\end{array}$ & 711311158 & $08.30-21.00$ \\
\hline 3 & Hj. Eva Yunus & $\begin{array}{l}\text { kecamatan Seberang } \\
\text { Ulu I }\end{array}$ & $\begin{array}{l}104.7616767 \\
2.9981514\end{array}$ & 82178987744 & $08.30-21.00$ \\
\hline 4 & NZ Belido & $\begin{array}{l}\text { kecamatan Seberang } \\
\text { Ulu I }\end{array}$ & $\begin{array}{l}104.7594372 \\
2.9981025\end{array}$ & - & $08.30-21.00$ \\
\hline 5 & Maulana 88 & kecamatan Plaju & $\begin{array}{l}104.810679 \\
2.995152\end{array}$ & 81278390959 & $06.00-22.00$ \\
\hline 6 & 189 & kecamatan Ilir Timur I & $\begin{array}{l}104.7498649 \\
2.9754531\end{array}$ & 711515248 & $08.30-21.00$ \\
\hline 7 & Y. Cek mansyur & $\begin{array}{l}\text { kecamatan Seberang } \\
\text { Ulu I }\end{array}$ & $\begin{array}{l}104.7620655 \\
2.9978433\end{array}$ & - & $08.30-21.00$ \\
\hline 8 & Deni & $\begin{array}{l}\text { kecamatan Seberang } \\
\text { Ulu II }\end{array}$ & $\begin{array}{l}104.768158 \\
2.9919729\end{array}$ & 711519586 & $08.30-21.00$ \\
\hline 9 & Eni Thoyieb & kecamatan Seberang & 104.7618398 & 82176670513 & $06.00-22.00$ \\
\hline
\end{tabular}




\begin{tabular}{|c|c|c|c|c|c|c|}
\hline & & Ulu I & 2.9980669 & & & \\
\hline 10 & Cek Jana & $\begin{array}{l}\text { kecamatan Seberang } \\
\text { Ulu I }\end{array}$ & $\begin{array}{l}104.7514161 \\
3.0109059\end{array}$ & - & 8994490227 & $08.30-22.00$ \\
\hline 11 & Kemplang755 & $\begin{array}{l}\text { kecamatan Seberang } \\
\text { Ulu I }\end{array}$ & $\begin{array}{l}104.7567293 \\
3.013088\end{array}$ & - & 7113005166 & $07.00-19.00$ \\
\hline 12 & Falen56 & kecamatan Bukit Kecil & $\begin{array}{l}104.7508998 \\
2.9902515\end{array}$ & - & 711510959 & $07.00-19.00$ \\
\hline 13 & Doa Ibu & $\begin{array}{l}\text { kecamatan Seberang } \\
\text { Ulu II }\end{array}$ & $\begin{array}{l}104.7684832 \\
2.9901516\end{array}$ & - & 7118418599 & $07.30-21.00$ \\
\hline 14 & Lidya & kecamatan Bukit Kecil & $\begin{array}{l}104.7546143 \\
2.9910576\end{array}$ & - & 81367227088 & $07.30-21.00$ \\
\hline 15 & Laylay & $\begin{array}{l}\text { kecamatan Ilir Timur } \\
\text { II }\end{array}$ & $\begin{array}{l}104.7799519 \\
2.9710473\end{array}$ & - & 82181419207 & $06.00-22.00$ \\
\hline 16 & Angan & $\begin{array}{l}\text { kecamatan Ilir Timur } \\
\text { II }\end{array}$ & $\begin{array}{l}104.7839067 \\
2.9722587\end{array}$ & - & 711311713 & $06.00-22.00$ \\
\hline 17 & Yenny & $\begin{array}{l}\text { kecamatan Ilir Timur } \\
\text { II }\end{array}$ & $\begin{array}{l}104.7792975 \\
2.9703864\end{array}$ & - & 711376264 & $08.30-21.00$ \\
\hline 18 & Biko 6003 & $\begin{array}{l}\text { kecamatan Ilir Timur } \\
\text { II }\end{array}$ & $\begin{array}{l}104.7842403 \\
2.9615244\end{array}$ & - & 81373887440 & $08.30-21.00$ \\
\hline 19 & Ummi & kecamatan Bukit Kecil & $\begin{array}{l}104.7549917 \\
2.9797891\end{array}$ & - & - & $07.00-22.00$ \\
\hline 20 & Kemplang Aleng & kecamatan Ilir Timur I & $\begin{array}{l}104.7698725 \\
2.9814965\end{array}$ & - & - & $07.00-21.00$ \\
\hline 21 & Dusun Aniez & $\begin{array}{l}\text { kecamatan Alang- } \\
\text { alang Lebar }\end{array}$ & $\begin{array}{l}104.6803434 \\
2.9153246\end{array}$ & & - & $07.00-21.00$ \\
\hline
\end{tabular}

Tabel 3. Data Spasial dan Non Spasial UMKM Songket

\begin{tabular}{|c|c|c|c|c|c|}
\hline No & Nama & Alamat & $\begin{array}{l}\text { Titik } \\
\text { Koordinat }\end{array}$ & No.TLP & Buka \\
\hline 1 & Zainal Songket & kecamatan Ilir Barat II & $\begin{array}{l}104.75276 \\
2.997567\end{array}$ & 811141874 & $08.00-17.00$ \\
\hline 2 & Cek Rody & kecamatan Ilir Barat II & $\begin{array}{l}104.75188 \\
2.997893\end{array}$ & 711367683 & $08.00-17.00$ \\
\hline 3 & Fikri Koleksi & kecamatan Ilir Barat II & $\begin{array}{l}104.745049 \\
2.994769\end{array}$ & 711367683 & $08.00-17.00$ \\
\hline 4 & Cek Ipah & kecamatan Ilir Barat II & $\begin{array}{l}104.7525671 \\
-2.9976265\end{array}$ & 711371021 & $08.00-17.00$ \\
\hline 5 & Cek Onah & kecamatan Ilir Barat II & $\begin{array}{l}104.752371 \\
2.997691\end{array}$ & - & $08.00-17.00$ \\
\hline 6 & Serengam Setia & kecamatan Ilir Barat II & $\begin{array}{l}104.74869 \quad- \\
3.002618\end{array}$ & - & $08.00-17.00$ \\
\hline 7 & Laila Songket & kecamatan Ilir Barat II & $\begin{array}{l}104.7524696 \\
-2.9976574\end{array}$ & - & $08.00-17.00$ \\
\hline 8 & Makmur Jaya & kecamatan Ilir Barat II & $\begin{array}{l}104.7518161 \\
-2.9979712\end{array}$ & 711367684 & $08.00-17.00$ \\
\hline 9 & Gelora Songket & kecamatan Ilir Barat I & $\begin{array}{l}104.7363685 \\
-3.0026722\end{array}$ & 8153553720 & $08.00-17.00$ \\
\hline 10 & Rumah Limas & kecamatan Ilir Barat I & $\begin{array}{l}104.7340554 \\
-2.9677893\end{array}$ & - & $08.00-17.00$ \\
\hline 11 & Pesona Bari & kecamatan Bukit Kecil & $\begin{array}{l}104.75766- \\
2.98655\end{array}$ & 711410572 & $08.00-17.00$ \\
\hline 12 & Tujuh Saudara & kecamatan Bukit Kecil & $\begin{array}{l}104.7457574 \\
-2.9937334\end{array}$ & 711366770 & $08.00-17.00$ \\
\hline
\end{tabular}


13 Rizal Songket

14 R. Busana Tria

15 Sabillah Safira

16 Gelora Songket

17 Harapan Baru

18 Benang Mas

29 Cantik Manis

20 Cek Yati

$\begin{array}{lll}\text { kecamatan Seberang } & 104.7698005 & 811711165 \\ \text { Ulu II } & -2.9904729 & \\ \text { kecamatan Ilir Barat I } & 104.7395572 & 711510831 \\ & -2.9763036 & \\ \text { kecamatan Ilir Barat I } & 104.7414947 & 711356798 \\ & -3.001557 & \\ \text { kecamatan Ilir Barat I } & 104.7363685 & 711444774 \\ & -3.0026722 & \\ \text { kecamatan Ilir Barat II } & 104.7490713 & 711310140 \\ & -2.9966186 & \\ \text { kecamatan Ilir Barat II } & 104.7486898 & - \\ & -2.9961796 & \\ \text { kecamatan Ilir Barat II } & 104.7488856 & - \\ & -2.9963882 & \\ \text { kecamatan Seberang } & 104.7687136 & 711363670 \\ \text { Ulu II } & -2.9910698 & \\ & & \end{array}$

08.00-17.00

$08.30-17.30$

08.30-17.30

08.00-17.00

08.00-17.00

08.00-17.00

08.00-17.00

08.00-17.00

\section{HASIL DAN PEMBAHASAN}

Hasil dari penelitian ini adalah sebuah pemetaan usaha kecil dan menengah produk khas kota Palembang berbasis sistem informasi geografis yang dibuat menggunakan arcgis 10.2. Hasil Penelitian ini diuraikan sebagai berikut.

\subsection{Dijitasi}

Hasil digitasi menampilkan layer kecamatan, yang dimana pada layer sistem infromasi geografis dikota Palembang terdapat 16 layer kecamatan yang dapat dilihat pada gambar 1.

\subsection{Hasil Input Data Titik Koordinat}

Pada input data, pengembang membuat titik titik koordinat yang sudah ditentukan diawal yaitu;

a) Titik koordinat pempek

b) Titik Koordinat Kerupuk Kemplang

c) Titik Koordinat Songket

Titik koordinat tersebut dapat dilihat pada gambar 2.

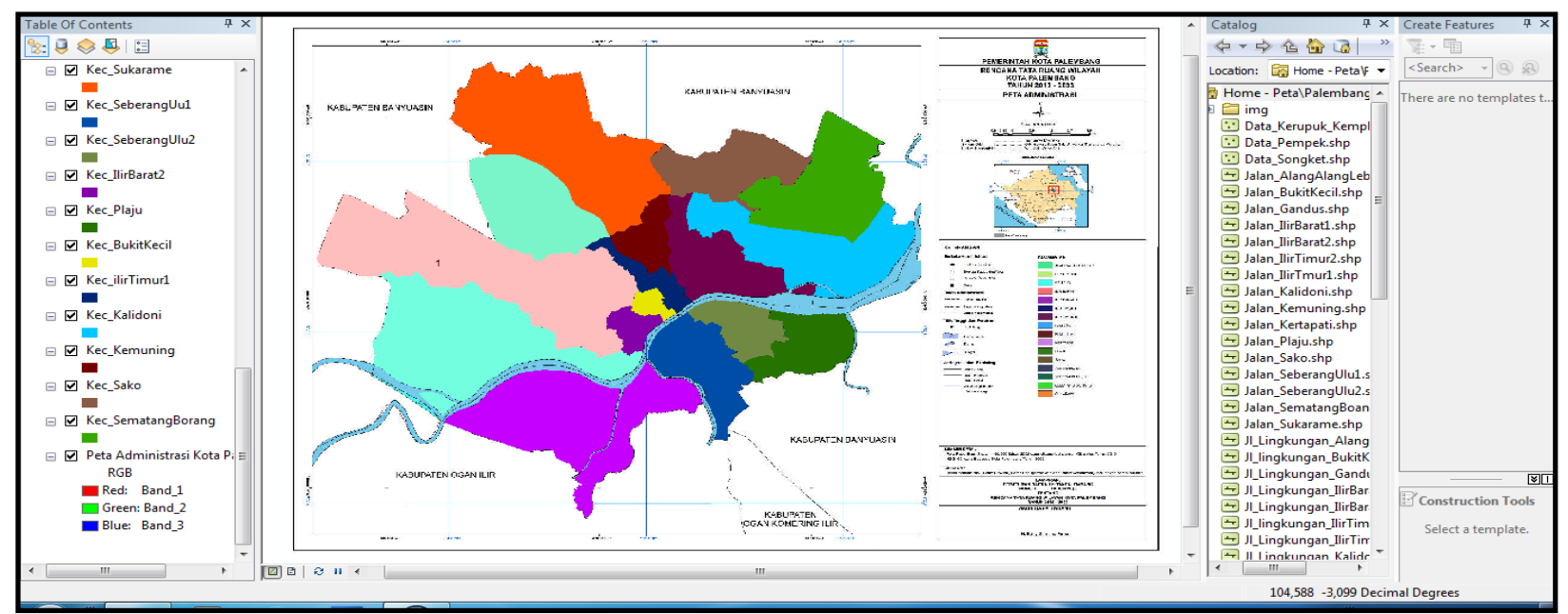

Gambar 1 Dijitasi Layer Kecamatan

Implementasi Sig Untuk Pemetaan Usaha Mikro, Kecil Dan Menengah (UMKM)... ... (Eka Puji Agustini) 


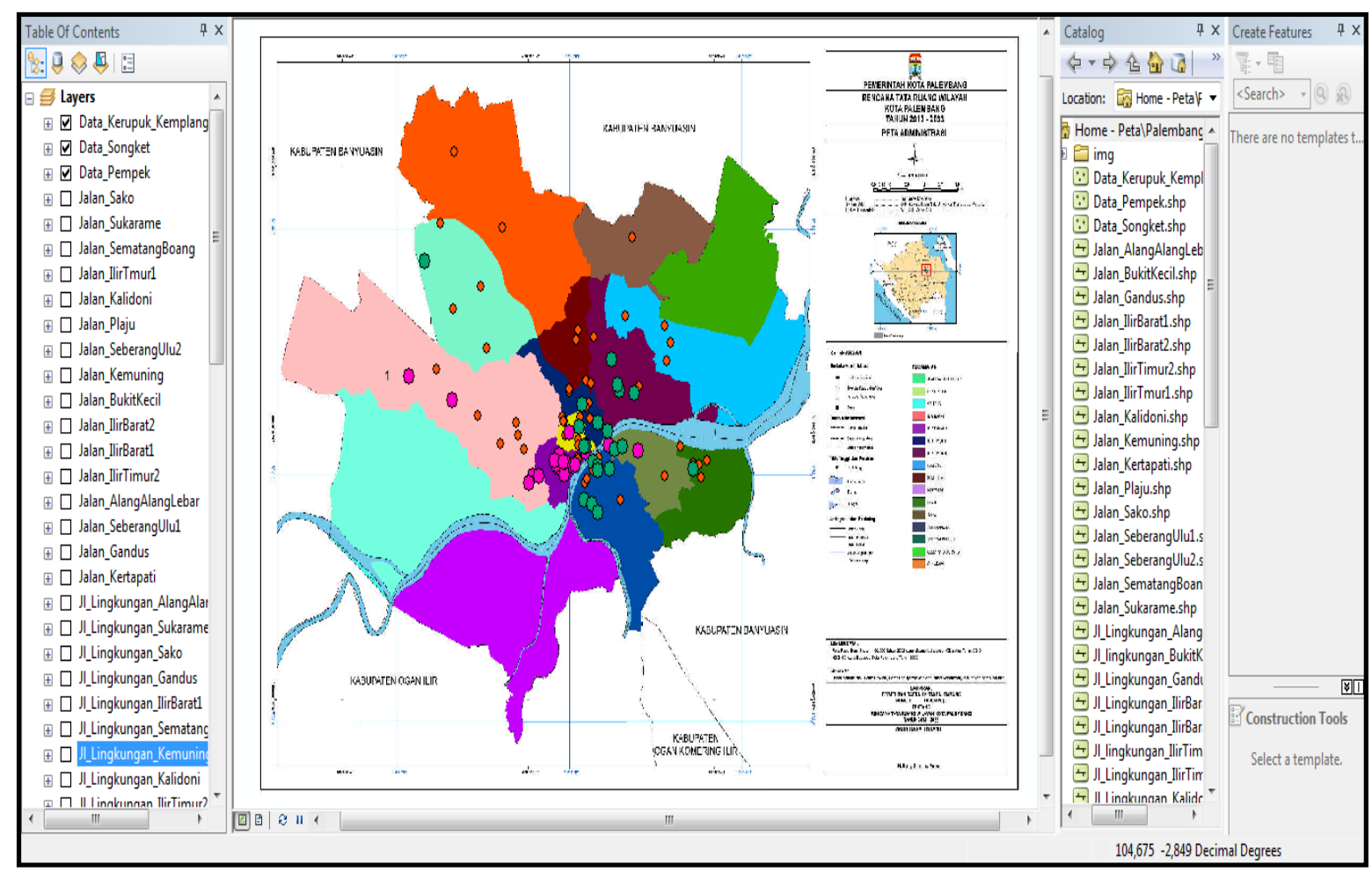

Gambar 2. Hasil Titik Koordinat

\subsection{Me-manage \& Memanipulasi data Attribute}

Hasil pada tahapan Me-manage \& Memanipulasi data adalah peng-entryan data produk khas Palembang tersebut seperti memasukkan nama - nama dari produk khas palembang, lokasi produk khas palembang, titik titik koordinat dengan menggukan open atribut table pada argis. Yang dapat dilihat pada gambar 3.

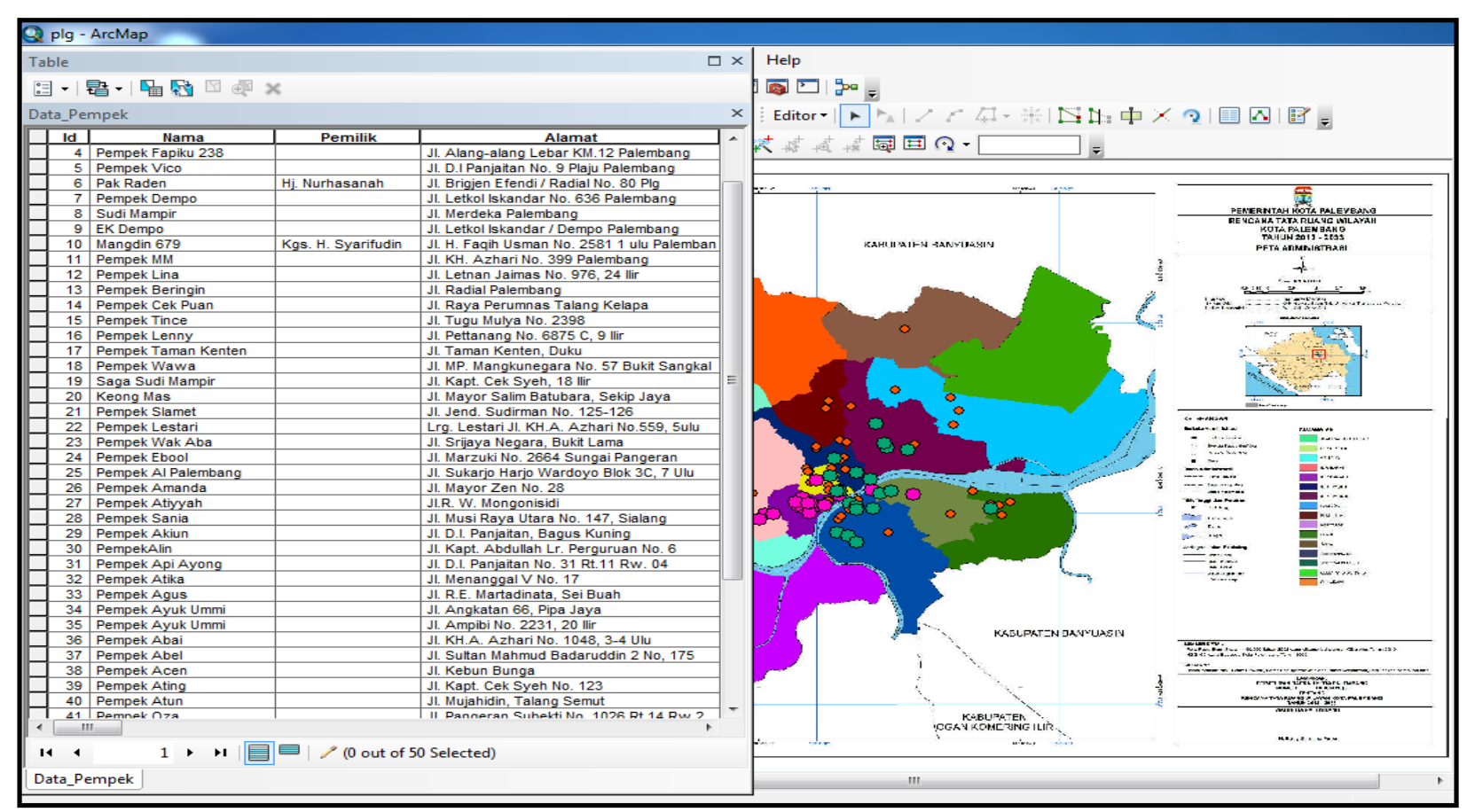

Gambar 3. Open Atribut Table 


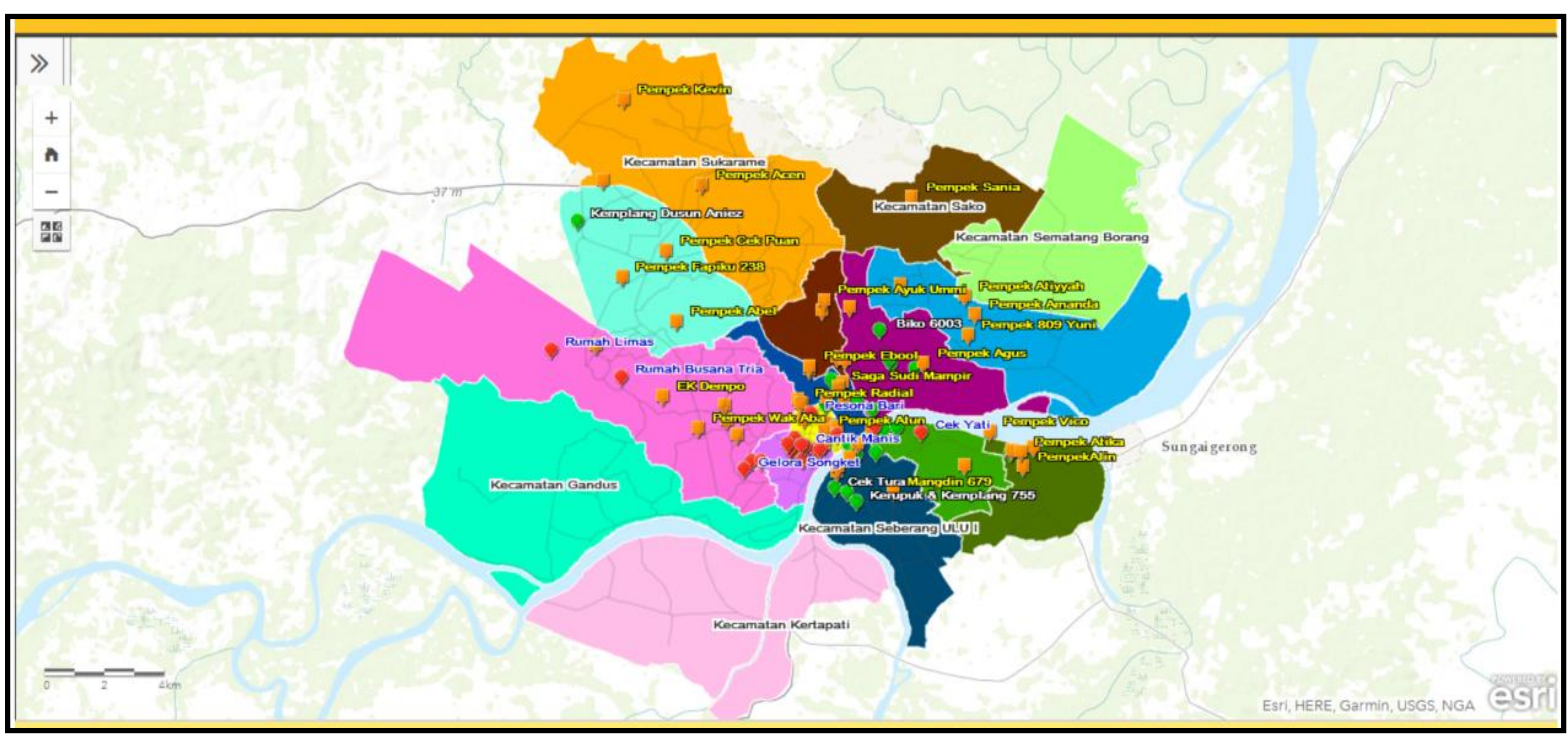

Gambar 4. Halaman Menu Peta SIG

\subsection{Menu Peta $S I G$}

Pada menu Peta SIG (Sistem Informasi Geografis) menampilkan sistem yang dibuat dengan mengunakan argis 10.2 Menu Peta SIG terlihat pada gambar 4 .

\section{KESIMPULAN}

Penelitian yang lakukan untuk Pemetaan Usaha Kecil dan Menengah Produk khas kota Palembang berbasis Sistem Informasi Geografis data menghasilkan sebuah Pemetaan Usaha kecil dan Menengah produk khas Palembang berbasis sistem informasi geografis di kota Palembang. Dengan menggunakan arcgis 10. 2. Dengan adanya pemetaan ini dapat membantu dinas terkait untuk mengolah data UMKM secara geografis dan mempercepat dalam memberikan informasi dalam hal pembinaan UMKM.

\section{DAFTAR PUSTAKA}

[1] D. Rahmat, T. Yang, and M. Esa, "www.hukumonline.com," no. 1, 2008, pp. 1-24.

[2] P. E. Prasetyo, "Peran Usaha Mikro Kecil dan Menengah (UMKM) dalam Kebijakan Penanggulangan Kemiskinan dan Pengangguran," J. Akunt. dan Manaj. , vol. 2, no. 1, pp. 1-13, 2008.

[3] www.palembang.go.id, "geografis @ www.palembang.go.id.” .

[4] Sriwijayatv.com, "434de46976277813f7e005347c7c230e3 7434e13@ sriwijayatv.com.”.

[5] Kholil, "Pemanfaatan Sistem Informasi Geografis (Sig) Dalam Aplikasi Pelaporan Dan Pelacakan Kejahatan Berbasis Android," J. Teknol. Inf. Dan Komun., vol. 6, no. 1, pp. 1-8, 2017.

[6] R. Sofyan, M. Isya, M. Anggraini, "Pemanfaatan Sistem Informasi Geografis (Sig) Untuk Prioritas Penanganan Jalan Di Kabupaten Aceh Besar," J. Tek. Sipil, vol. 1, no. 1, pp. 167-176, 2017.

[7] K. M. Wibowo, K. Indra, and J. Jumadi, "Sistem Informasi Geografis (SIG) Menentukan Lokasi Pertambangan Batu Bara di Provinsi Bengkulu Berbasis Website," J. Media Infotama, vol. 11, no. 1, pp. 51-60, 2015.

[8] A. K. Hua, "Sistem Informasi Geografi (GIS): Pengenalan kepada perspektif 
komputer," Sist. Inf. Geogr. Pengenalan Kpd. Perspekt. Komput. (Geographic Inf. Syst. Introd. to Comput. Perspect., vol. 11, no. 1, pp. 24-31, 2015, doi: 10.6084/m9.figshare.1491406.v1.

[9] MUHAMMAD YOGI ANGGA HUTAMA SIREGAR, "Tinjauan Pustaka," Implement. Sci., vol. 39, no. 1, pp. 1-24, 2014, doi: $10.4324 / 9781315853178$.

[10] M. J. Vardaro et al., "Data Non Spasial,"

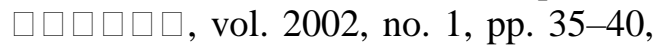
2016, doi: 10.1109/ciced.2018.8592188. 